Forgotten Disease 
This page intentionally left blank 
STUDIES OF THE WEATHERHEA D EAST A S I A I I S T I T U T E, C O L U M B I A U N IVERS I T Y

The Studies of the Weatherhead East Asian Institute of Columbia University were inaugurated in I962 to bring to a wider public the results of significant new research on modern and contemporary East Asia.

A complete list of titles is available online at weai.columbia.edul publications/studies-weai/. 
This page intentionally left blank 


\section{Forgotten Disease}

I L L N ES S S TRAN S FORME D I N C H I N E S M E D I C I N E

Hilary A. Smith

STANFORD UNIVERSITY PRESS

S T A N F O R D, C A L I F O R N I A 
Stanford University Press

Stanford, California

(C) 2017 by the Board of Trustees of the Leland Stanford Junior University. All rights reserved.

No part of this book may be reproduced or transmitted in any form or by any means, electronic or mechanical, including photocopying and recording, or in any information storage or retrieval system without the prior written permission of Stanford University Press.

Printed in the United States of America on acid-free, archivalquality paper

Library of Congress Cataloging-in-Publication Data

Names: Smith, Hilary A., author.

Title: Forgotten disease : illnesses transformed in Chinese medicine / Hilary A. Smith.

Other titles: Studies of the Weatherhead East Asian Institute, Columbia University.

Description: Stanford, California : Stanford University Press, 2017. | Series: Studies of the Weatherhead East Asian Institute, Columbia University | Includes bibliographical references and index.

Identifiers: LCCN 2017000968 | ISBN 978 I 503602090 (cloth : alk. paper) | ISBN 978 I 503603448 (pbk. : alk. paper) | ISBN 978 I 503603509 (epub)

Subjects: LCSH: Beri-beri-China-History. | MedicineChina-History. | Foot-Diseases_China-History. | Medical literature-China-History.

Classification: LCC RC627.B45 S45 2017 |

DDC 6I0.95 I-dc23

LC record available at https://lccn.loc.gov/2017000968

Typeset by Thompson Type in I I/I 4 Adobe Garamond 